\title{
Solar Energy Scenarios
}

\author{
Mr Vishwanath K Patel \\ Mewad University, Mechanical Department, Chittorgarh, Rajasthan
}

\begin{abstract}
The Crises of energy has been increased over the years due to increasing world population and expansion of global industries especially for food and basic requirements. Most of the energy is consumed in power generation, industries \& factories, transportation, and community sectors. Moreover, in order to fulfill our demand we are mostly dependent on energy, taken from fossil oil, gas and coal. In developing countries like India, more than $70 \%$ of the population lives in the rural areas where more than $85 \%$ of the energy being consumed comes from non-conventional sources, the major one being fuel wood. The increasing cost of conventional fuel in urban areas necessitates the exploration of other energy sources. Solar energy provides an alternate source of energy in rural and urban India as a substitute for fossil fuels. We can get the solar energy from sun; the sun is a major source of solar energy. In Gujarat the fossil resources are limited, and they impose a high burden on the environment therefore looking at the ecological and economical perspectives, solar energy is an important source of energy for the state. Thus as effective Solar energy is strategic the review highlights the various Solar energy scenarios that can facilitate the vision of a cleaner environment and to effectively deal with the energy crises problems.
\end{abstract}

Keywords: - Solar energy, Energy crisis

\section{Solar Energy And Gujarat}

The range of application of Solar energy in Gujarat is currently being limited to applications in the developing world such as India, Africa, and the Philippines for uses such as cooking fuel and heating homes [1, 2]. After independence it was realized that the country was facing severe power shortage. Therefore there was a crying need to overcome this shortage by rendering services and making the availability of Renewable Energy Sources in the most rural parts of the country. Therefore from a primitive stage long term R\&D goals were set to enhance the idea of renewable energy in Gujarat state with a ultimate aim to enlighten each and every house, facing power problems. Furthermore R\&D aimed to effectively utilize renewable sources of energy like the Sun, biomass and wind to provide sophisticated services with generation of employment. Thus, solar energy development in Gujarat can facilitate the vision of a energy-independent state and ultimately can add to the country's economy.

Looking at Gujarat's ecological and economical perspectives, solar energy is an important source of energy. The fossil resources are limited, and they impose a high burden on the environment. Solar energy units for heating water are commercially available and used by millions of people in various parts of the world. solar energy use in solar water heating system, In this system low and medium temperature process heat requirements hot water up to $90^{\circ} \mathrm{C}$,hot air up to $110^{\circ} \mathrm{Cand}$ low pressure steam up to $140^{\circ} \mathrm{C}$. Solar radiation plays the most important role for generation of solar energy .Mainly three parts of solar radiation,

\section{GLOBAL RADIATION = BEAM RADIATION + DIFFUSE RADIATION}

Solar radiation is depends upon the wavelength of solar rays. The percentage of solar radiation obtained up to a certain wavelength is also given in Table.

\begin{tabular}{|l|l|l|l|}
\hline $\begin{array}{l}\text { Wavelength of solar } \\
\text { ray } \\
(\mu)\end{array}$ & $0-0.38$ & $0.38-0.78$ & $0.78-4.0$ \\
\hline $\begin{array}{l}\text { Approximate energy } \\
\left(W / m^{2}\right)\end{array}$ & 95 & 640 & 618 \\
\hline $\begin{array}{l}\text { Approximate } \\
\text { percentage of total } \\
\text { energy }\end{array}$ & $7 \%$ & $47.3 \%$ & $45.7 \%$ \\
\hline
\end{tabular}

In Gujarat, Gujarat state Electricity corporation Ltd.had set up a 1MW solar power plant on Narmada canal of Sardar Sarovar Nigam Ltd.near chandrasan village in kadi taluka in Gujarat. This unique Project prevents water evaporation from the canal to the tune is 90 lakh litres annually besides saving land required from the project.Besides,efficiency of the solar modules go up,due to the water from the canal cools them.

Gujarat Solar Park is the name used for a group of solar parks being constructed in Gujarat. Certificates of completion were issued on April 19, 2012 for a total of $605 \mathrm{MW}$, but this includes sections that were already 
operational. One is the Charanka Solar Park a group of 17 thin-film photovoltaic (PV) power systems, on a 2000 ha site in the district of Patan.

At completion the project will save around 8 million tonnes of carbon dioxide of being released into the atmosphere and around 900,000 tonnes of coal and natural gas per year. The $600 \mathrm{MW}$ is expected to save 900,000 tones of natural gas, and reduce $\mathrm{CO}_{2}$ emissions by eight million tones, annually. A total of 84 developers have registered to build a total of $968.5 \mathrm{MW}$, from 1 to $40 \mathrm{MW}$. $1000 \mathrm{MW}$ is expected to be completed by 2013 .

\section{INDIA AND ENERGY}

The role of energy in India's economy has become globally relevant in recent years due to the country's high economic growth and rising concerns about the environmental impacts of energy use. Primary energy demand grew at the rate of 6 per cent a year between 1981 and 2001 (Planning Commission, 2002), and India now ranks fifth in the world in terms of primary energy consumption. It accounted for about 3.5 per cent of the world's commercial energy demand in 2003. Although there has been a gradually increasing dependency on commercial fuels, a sizeable amount of the national energy requirement, especially in the rural household sector, continues to be met by noncommercial energy sources. These include fuel wood, crop residue, and animal waste, as well as human and draught animal power. Future economic growth will lead to a rapid increase in demand for commercial energy higher levels of urbanization, and adoption of modern lifestyles. The Renewable Energy Plan 2012 calls for achieving a 10 percent share for renewable energy in incremental power capacity by adding about 10,000 MW of new renewable energy (RE) based generation. In addition to the gridconnected RE goal, other major RE initiatives include-installment of 1 million household solar water heating systems; electrification by renewable mini-grids for 24,000 villages without electricity; deployment of 5 million solar lanterns and 2 million solar home lighting systems; (4) and establishment of an additional 3 million small biogas plants. The Electricity Act of 2003 has provided a major thrust to RE technologies via its mandate: "To promote cogeneration and generation of electricity through renewable sources of energy by providing suitable measures for connectivity with the grid and sale of electricity to any persons, and also specifying, for purchase of electricity from such sources, a percentage of the total consumption of electricity in the area of a distribution licensee." The National Electricity Policy of 2005 gives each State regulator authority to create a Renewable Energy Portfolio Standard for the transmission and distribution companies serving their jurisdictions.

The Ministry of New and Renewable Energy (MNRE) is involved in the development, demonstration and utilization of various renewable energy-based technologies, including Solar Thermal, Solar Photovoltaic's, Wind power, Biomass combustion/co-generation, Small Hydro power, Biogas, Geothermal, Waste-to-energy, and tidal power. Major MNRE activities include: (i) Project development and financing of RE-based grid power; (ii) Urban solar hot water heaters; (iii) resource mapping. India has the most developed and diversified renewable energy market. The Government of India has set a goal of electrifying 18,000 remote villages and meeting 10 percent of the country's power supply through RE by 2012. These targets are in addition to those fixed for other RE devices or programs, including establishing 1 million solar PV systems for lighting; 8,000 solar PV pumps for irrigation; 10,000 solar PV generators, stand-alone solar PV power plants, solar water heating systems, solar air heating systems, and solar cookers, including large steam cooking systems; 360 energy demonstration parks, and; more solar retail outlets and solar passive buildings.

\section{Conclusion}

Although renewable energy power generation is a genuine clean development success story, there are some problems that need to be addressed to make the industry sustainable and self-supporting. There is currently some retrenchment going on with respect to RE policy amongst the State regulators. States with strong RE policies include Andhra Pradesh, Tamil Nadu, Maharashtra, and Gujarat. A strong RE policy consists of: (i) Preferential treatment; (ii) Portfolio standards; and (iii) Standardized PPA. However, care must be taken towards over-subsidizing renewable energy development relative to other energy sources at the expense of rate payers and taxpayers. The disaggregate nature of implementing the Electricity Act's renewable energy portfolio standards has created considerable disparities and lack of analytic basis for the relative pricing of various forms of RE within and between different States (e.g., Hydro gets a lower price than Wind or Biomass in one state, or the price is very different between two adjacent states). Because the price made available to RE project developers does not seem to be firmly grounded, transmission and distribution licensees are going to court to avoid entering into power tariffs for purchases of renewable energy. There is a need for standard methods of valuation of the relative environmental benefits accruing to different forms of RE, which could then be reflected in PPA price differentials RE resources should also play a bigger role in providing decentralized power to remote areas, in line with the goal of providing modern energy access to all by 2012. Decentralized power generation, especially in remote locations where the grid cannot be extended, should necessarily be based on RE forms to provide these regions with access to clean and reliable energy. 


\section{References}

[1] Report of Gujarat Energy Development Agency,Gujarat, India

[2] Newspaper(Gujarat samachar,The Times of India etc.)

[3] www.google.com

[4] Non-conventional Energy Sources by G.D.Rai ( khanna Publications)

[5] journals and various reports 